\title{
IO. COMMISSION DES TACHES SOLAIRES ET DES NOMBRES CARACTERISTIQUES
}

\author{
PRÉsident: M. M. WALDMEIER, Direktor der Eidgenössischen Sternwarte, Zürich, Schweiz. \\ Membres: MM. Abetti, Alfvén, Brunner, Brunner-Hagger, Burton, S. Chapman, \\ d'Azambuja, Guth, Heines, Newton, Nicholson, Romañá, Rowland, Stratton.
}

\section{RESEARCH WORK}

Introduction. Ten years have passed since the last Congress and so much has been published since then in the field of photospheric and allied phenomena that this can only be a summary and not an exhaustive report.

Periodicity of Sunspot Activity. The long period already established by R. Wolf in I862, has again been investigated by W. Gleissberg (Publ. Istanbul Obs. No. I4, I94I; No. I5, r94I; $Z . A p .21,347,1942 ; A p . J .96,234,1942)$, with the result that the period amounts to approximately 70 years.

Prediction of Sunspot Activity. For the first time, thanks to the outburst hypothesis established by M. Waldmeier in I935, it has been possible to predict the whole course of a new cycle at its beginning. The essential point of that hypothesis brings out the fact that the totality of the individual sunspot cycles forms a family of curves depending on chiefly one parameter. Later on, different analytical formulae have been suggested for these curves by Stewart and Panofsky $(A p . J .88,385$, I938; 91, 72, I940) and by W. Gleissberg (Z.Ap. I8, 199, I939). These formulae have, however, proved less adequate for the prediction, because they contain as parameter the Sun's activity at its maximum, so that they only can be used after the maximum has been reached. M. Waldmeier's prediction having proved successful (A.N. 259, 267, 1936), a new prediction with the help of the same method was set up at the beginning of the current cycle (Terr. Mag. 5r, 270, 1946), according to which the maximum should be extremely intensive and should take place in 1947.6. As far as can be judged from the observations at the present stage, this prediction was fully successful too. W. Gleissberg predicted the present sunspot cycle as follows (Nature, 156, 539, r945): With a probability of $95 \%$ it can be predicted that the maximum will take place before May 1948 and will be greater than that of 1937 .

Distribution of the Sunspot Groups on the Sun's Disk. An investigation of the latitude of the spot zone during 7 cycles by M. Waldmeier (Astron. Mitt. Zürich, No. I38, 470, I939) has led to the result that, contrary to the frequency variation, the latitude variation is very regular; as a further consequence the average latitude of the spot zone during very intensive, that is to say premature maxima, is greater than during weak and thus late maxima. W. Gleissberg has come to the same conclusion (Publ. Istanbul Obs. No. 20, I942 and $A p . J$. 100, 219, 1944).

The east-west asymmetry has been examined by W. Gleissberg (A.N. 268, 8I, I939), M. G. J. Minnaert (A.N. 269, 48, 1939) and M. Waldmeier (Astron. Mitt. Zürich, No. 138, $460,1939)$. In all these three publications the excess of originating sunspots on the eastern side compared to the western side is explained by the variable visibility of sunspots, dependent on the distance from the centre of the Sun's disk, in connection with the Sun's rotation. If this theory proves to be correct, there must be a corresponding excess on the western hemisphere as compared to the eastern one for the dissolution of sunspots. In the last quoted publication this effect has likewise been examined, leading to the result that the points, at which sunspots are seen for the last time, show a distribution conforming exactly to what had to be expected from the theory. Concerning the visibility of spot groups it has been found that not only a geometrical foreshortening had to be taken into account, but that there exists a 'physical foreshortening' too; see Dobbie (Obs. 62, 289, I939) and G. H. A. Archenhold (M.N. 100, 645, I940 and ror, 66, I94I). A further east-west asymmetry, suspected by Maunder, according to which the groups 
appearing on the eastern limb are more numerous than those disappearing on the western limb, has already been put into doubt by M. Waldmeier in his book Ergebnisse und Probleme der Sonnenforschung, Leipzig, I94I, and refuted by W. Gleissberg (Obs. 67, 6o, r947).

A third east-west asymmetry maintains that the area occupied by the spots on the eastern side of the Sun is greater than that occupied on the western side. This effect has been confirmed by Gleissberg ( $P u b l$. Istanbul Obs. No. I2, I940). It can be explained by a westerly inclination of the upper end of the spot's axis of approx. $0^{\circ} \cdot 5$. The reason for the small angle is apparently due to the fact that there are spots with easterly and others with westerly inclination, which are nearly equally frequent. In fact, according to W. Gleissberg ( $A p . J$. 102, I33, I945), there is for P-spots an area excess in the western hemisphere and for $\mathrm{F}$-spots in the eastern hemisphere, which seems to indicate that the upper end of the P-spots' axis is directed towards the east and that of the F-spots towards the west. According to M. G. J. Minnaert (M.N. 106, 98, 1946) the inclination is $0^{\circ} \cdot 44$ for all spots, $4^{\circ} \cdot 3$ to $6^{\circ} \cdot 8$ for those whose lifetime equals at least half a solar rotation and $7^{\circ} \cdot 6$ for lifetimes of at least one solar rotation.

Waldmeier has pointed out (Ergebnisse und Probleme der Sonnenforschung, Leipzig, I94I, Abb. 42) a relation between the northern and southern hemispheres. Recent, not yet published research work shows that, more often than should be expected from mere chance, a spot not only possesses a corresponding spot in the same longitude and symmetric to the equator, but that there often exists a corresponding pair of spots on the meridian situated $I 80^{\circ}$ away from the one considered.

Romañá has discussed other suspected asymmetries in the distribution of the spot positions, especially with regard to a probable 'earth-effect' (A soc. Espan. para el Prog. Cienc. Xvil, Cong. Córdoba, 1944).

The lifetime of spot groups has been examined by M. N. Gnevishev (Pulkova Obs. Cir. No. 24, I938; No. 30, I940). For more than half the groups the lifetime is shorter than two days and for more than $90 \%$ shorter than II days.

Structure of the Spots. In a publication (Astron. Mitt. Zürich, No. I38, 439, I939) Waldmeier showed that a normal sunspot consists of three different parts: umbra, penumbra and bright ring, and has determined the corresponding diameters of these three parts. A theoretical investigation yields a level difference of about $50 \mathrm{~km}$. between photosphere and spot (Helv. Phys. Acta, 15, 4r6, 1942), whereas E. Pettit (Ann. Rep. Mt Wilson Obs. p. 12, r939) lately seems to have found a confirmation of the Wilson effect. The great level differences of 1000 to $2000 \mathrm{~km}$. are ascribed to the bright ring.

Proper Motions. Using observations made in 1936 and I937 M. Waldmeier (Astron. Mitt. Zürich, No. I38, 45 I, I939) has made an investigation on a particular form of proper motions; of special interest are the groups with a strong meridional motion or which penetrate each other. J. Tuominen $(Z . A p . \mathbf{2 1}, 96$, I942) ascertains a peculiar periodic increase and decrease of the meridional speed and he gives a model interpretation for the great meridional motions which occasionally occur at the birth of spot groups (Obs. 66, 387, I946).

Magnetic investigations, which for decades had been the privilege of the Mt Wilson Observatory, were included since 1942 by $H$. v. Klüber in the routine programme of the Einstein Institute at Potsdam (Z.Ap. 24, I, I2I, I947). R. S. Richardson (Ann. Rep. $M t$ Wilson Obs. p. 9, I939/40) has proved that outside the spots there exists a magnetic field, opposite in sign to that of the umbra and with $5 \%$ of its intensity. T. G. Cowling (M.N. ro6, 218, I947) finds from theoretical considerations that the growth of a magnetic field requires some hundred years so that the magnetic field of sunspots cannot have originated in the spot, but must have existed long before they reached the Sun's surface and thus became visible. S. Chapman (Terr. Mag. 49, 37, I944) has made calculations of the magnetic field at the sunspot ends of a semicircular electromagnet in the form of half an anchor-ring.

Solar Radiation at Radio-frequencies. In February I942, J. S. Hey first noticed this radiation during the passage of a large spot group (Nature, 156, 534, I945; 157, 47 and 296 , I946). Whereas there is no doubt that this radiation originates from the Sun, it is 
quite clear that only a certain component of it is connected with the sunspots. From the available observations M. Waldmeier (Astron. Mitt. Zürich, No. I54, r948) concludes to the existence of a component emitted continuously from the Sun, $R_{k}$, and a component emitted eruptively, $R_{e} . R_{k}$ itself can again be decomposed in a component $R_{k, c}$ originating from the corona, and $R_{k, s}$ closely connected with the spots. We only have to report about the latter. This radiation shows an intensive 'limb darkening', as it reaches the earth only if the distance of its source from the centre of the Sun's disk is not greater than half the Sun's radius. Different authors confirm that this radiation is circularly polarized, and that its frequency is in accordance with the gyromagnetic frequency of the electrons in the magnetic field of the spots: D. F. Martyn (Nature, r58, 308, I946), E. V. Appleton and J. S. Hey (Nature, 158, 339, I946), Denisse (Rev. Sci. 84, 259, I946), K. O. Kiepenheuer (Nature, 158, 340, I946), L. L. McCready, J. L. Pawsey and R. PayneScott (Proc. Roy. Soc. 190, 357, I947), T. V. Garwick (C.R. 224, 377, 55I, I947).

Photometry. New investigations made by R. S. Richardson $(A p . J .90,230$, I939) on different wave-lengths at different distances from the Sun's centre show that the conditions observed in the umbra can best be represented by radiative equilibrium of a temperature of $4300^{\circ}$.

Theories about Spots and Spot-cycles. M. Waldmeier (Helv. Phys. Acta, 15, 405, I942) has given a qualitative and quantitative explanation of the Evershed effect, based on a model solar atmosphere for the undisturbed photosphere and for the sunspot.

G. J. Odgers tried to explain the structure of the sunspots on the assumption that a spot is a region in which the product of absorption coefficient and density is higher than that of the photosphere (M.N. ro6, IOI, I946). H. Alfvén brings the cooling in the sunspots in connection with their magnetic field (Ark. Mat. Astron. Fysik, 29 A, No. II, I943). As a consequence of the additional magnetic pressure the gas pressure in the spot must be smaller than in the photosphere in the state of equilibrium. Gas flowing up in the spot will thus undergo a much stronger process of cooling than in undisturbed regions.

An exhaustive theory about the II-years cycle has been set up by H. Alfvén ( $A r k$. Mat. Astron. Fysik, 29 B, No. 2, I942 and 29 A, No. I2, I943; M.N. 105, 3 and 382, I946) and H. Walén (Ark. Mat. Astron. Fysik, 3o A, No. I5, I944), according to which the disturbances have their origin in the Sun's interior and move as magneto-hydrodynamic waves along the lines of force of the general magnetic field towards the Sun's surface, where they become visible as spots.

Faculae. Independently of one another P. ten Bruggencate $(Z$. Ap. 19, 59, 1939) and M. Waldmeier (Helv. Phys. Acta, 13, I4, I939) have discovered the fine structure of the faculae. These consist of individual faculae granules which have a diameter of $I-2^{\prime \prime}$ and a lifetime of about 2 hours. The faculae granules attain much greater intensities than the photospheric ones; P. ten Bruggencate ( $Z$. Ap. 21, I62, I942) finds that the brightest faculae granules exceed the photospheric granules by about $40-50 \%$.

Granulation. In the year 1938 there was a great confusion concerning the granulation, as the works of Potsdam and Oxford yielded much larger granules than the classical investigations. The situation became clear, when in the following years $\mathrm{Ph}$. C. Keenan (Ap. J. 88, 360, I938 and 89, 604, I939), P. ten Bruggencate and H. Müller $(Z . A p . \mathbf{2 1}$, I98, I942) and M. Waldmeier (Helv. Phys. Acta, r3, I4, I939) succeeded in obtaining photographs of greater resolution and, in accordance with the classical works, found that the diameter of the granules is about $x$ roo $\mathrm{km}$. The granulation theory, based on the hydrogen convection zone, has been further carried on by L. Biermann $(Z . A p$. 21, 320, I942) and R. v. d. R. Woolley (M.N. I03, I9I, I943).

Structure of the Solar photosphere. The discovery of the $\mathrm{H}^{-}$-absorption by $\mathrm{R}$. Wildt (Ap.J. 89, 295, I939; 90, 6II, I939) made a new calculation of the constitution of the Sun's atmosphere necessary. Such calculations have been carried out by B. Strömgren (Festschrift für E. Strömgren, p. 218, I940), M. Waldmeier (Helv. Phys. Acta, 15, 405, I942) and $G$. Münch $(A p . J$. ro2, 385, r945). They are based on earlier theoretical determinations of the absorption coefficient of $\mathrm{H}^{-}$and should be repeated with the results recently obtained by S. Chandrasekhar and F. M. Breen (AP. J. ro4, 430, 1946). 


\section{Report on the 'Quarterly Bulletin on Solar Activity'}

Up to the end of I94I the Bulletin appeared regularly, then, owing to lack of communications, it had to be suspended. The Bulletin for the years I942-44 appeared in autumn I945, for the years I945 and I946 in summer 1947 and for the first quarter I947 in December I947. At the end of I944 the publication of the character figures of solar phenomena was discontinued. Since 1947 the following indications are communicated in the Bulletin:

I. Sunspots:

(I) Sunspot relative-numbers.

(2) Evolution-tables of sunspot-groups.

II. Eruptions chromosphériques brillantes:

(I) Eruptions signalées.

(2) Régions actives.

(3) Heures effectives d'observations au spectrohélioscope et au spectrohéliographe.

III. Intensité de la couronne solaire:

(I) Observations d'Arosa.

(2) Observations de Climax.

(3) Observations du Pic du Midi.

(4) Observations du Wendelstein.

IV. Rayonnement solaire de fréquence radioélectrique.

(I) Flux et Bursts par heure.

(2) Outbursts.

Up to now the Bulletin does not contain indications about the prominences.

\section{SugGeSTIONS}

I. As the character figures have been cancelled, the title of the Commission: 'Commission des taches solaires et des figures caractéristiques solaires' is no longer up to date. We therefore suggest the new title: 'Commission des phénomènes photosphériques.'

2. The heliographic maps of the photosphere have been published by the Federal Observatory since the year I887. The latest maps appeared for the year I946 (Publ. der Eidgen. Sternwarte, Bd. IX, Heft I). The great increase of printing costs will no longer permit the publication of these important maps, if the I.A.U. cannot grant a subvention. By the collaboration of the observatories of Zürich, Arosa, Locarno, Istanbul, Kanzelhöhe, Madrid, Potsdam, Skalnate Pleso, Tsinan and Uccle the setting up of the heliographic maps of the Sun was made possible. These maps in connection with the evolution tables indicate the spots and faculae occurring at any time on the Sun as well as their distribution on the Sun's disk. A yearly subvention of S.fr. I500 is suggested.

\section{WALDMEIER President of the Commission}

\section{Comple rendu des séances}

Président: Prof. Dr M. WaldmeIer.

Secrétaire: Rév. Dr A. Romañá, S.J.

La Commission tint des séances le I2 et le I4 août, et conjointement avec la Commission II et la Sous-Commission pour la cinématographie des protubérances, le I4 et le I7. Après l'éloge des membres décédés depuis l'Assemblée de Stockholm (Rodés, Perepelkin, Newall), M. le Président rend compte de la désignation des nouveaux membres et propose 
d'en augmenter le nombre, pour que d'autres observatoires, collaborant depuis quelque temps aux travaux de la Commission (Skalnaté Pleso, Uccle, Madrid) puissent y être représentés; l'augmentation est approuvée, et l'on nomme aussi par acclamation, sur la proposition de M. Waldmeier, M. Brunner Président d'honneur de la Commission.

On entre dans l'ordre du jour et on discute le changement de nom de la Commission. Il semble bien qu'elle doive s'appeler désormais 'des phénomènes photosphériques', puisqu'elle s'occupe d'autres phénomènes que les taches, tels que les plages faculaires, la granulation, etc. Dans la discussion M. Menzel envisage une nouvelle organisation des commissions s'occupant du Soleil, qui devraient être à son avis au nombre de quatre: de la variabilité solaire et de ses rapports avec les phénomènes terrestres, de l'atmosphère solaire, de l'astrophysique solaire, et des éclipses; mais cette réorganisation dépassant les attributions de la Commission, après l'intervention de MM. Minnaert, d'Azambuja, Royds et Kaplan, on adopte la proposition. On décide aussi de demander au Comité des Finances une subvention annuelle de I500 francs suisses, jusqu'à la prochaine Assemblée, pour que la publication des cartes synoptiques de Zürich puisse être continuée. M. Brunner-Hagger suggère qu'il serait intéressant de remplir la lacune d'environ 20 ans existant avant I926; mais il faut y renoncer pour le moment à cause du travail extraordinaire et des frais que cela exigerait. M. d'Azambuja dit que, dans le but de suivre les plages faculaires dans l'ensemble du disque, il serait à souhaiter que leur observation ne se fît plus désormais en lumière intégrale, mais avec la raie $\mathrm{K}$ à l'aide de spectrohéliographes à faible dispersion. M. Waldmeier craint qu'une telle recommandation diminuerait de beaucoup le nombre des collaborateurs et $M$. Öhman fait remarquer que le même résultat peut être obtenu plus facilement avec des filtres pour l'ultra-violet.

On s'occupe du problème créé par l'augmentation des frais d'impression du Quarterly Bulletin. Après une discussion très détaillée (Gallet, Waldmeier, d'Azambuja, Abetti, Roberts, Kiepenheuer, etc.) on décide de la continuer pour le moment sous la même forme que jusqu'à présent, même pour les données sur la couronne, le temps écoulé depuis le commencement des observations de celle-ci semblant trop court pour qu'une standardisation puisse être faite. M. le Président profite de l'occasion pour remercier M. Stratton pour l'aide que l'on reçoit toujours du Conseil des Unions Scientifiques grâce à son appui.

On étudie finalement une proposition de $\mathbf{M}$. Waldmeier concernant l'organisation d'une collaboration internationale, sous la conduite de l'Observatoire de Zürich, dans le but de connaître en détail l'évolution des taches, soit par l'utilisation des données déjà existantes, soit par la prise systématique de photographies fréquentes de ces taches dans l'avenir. Après une discussion sur la forme la plus pratique de cette collaboration (Menzel, d'Azambuja, Romañá, Brunner-Hagger, Kiepenheuer, Ellison), suivie d'autres suggestions fort intéressantes sur la possibilité d'étudier les mouvements propres des taches aux régions boréales en été (Tuominen, Abetti, Atkinson, Fracastoro), la proposition est adoptée et l'on confie à M. Waldmeier son exécution. 